\title{
Inconsistencies in Autism-Specific Emotion Interventions: Cause for Concern
}

\author{
Monica Caldeira \& Alan Edmunds \\ Western University
}

\begin{abstract}
Precise educational interventions are the sine qua non of services for students with exceptionalities. Applying interventions riddled with inconsistencies, therefore, interferes with the growth and learning potential of students who need these interventions. This research synthesis documents the inconsistencies revealed during a critical analysis of the procedures and outcomes of emotion intervention studies for individuals with Autistic Disorder and Asperger's Disorder. The authors examined all peer-reviewed emotion intervention studies published in English between 1985 and 2010 in the PsycInfo, ERIC, and Medline databases (N $=24)$. It is noteworthy that while $96 \%$ of studies reported improvements in emotion abilities post-intervention, these improvements were notably limited in the majority of cases and many studies demonstrated methodological inconsistencies. Specific suggestions are made for mitigating such inconsistencies in order to provide individuals with Autistic Disorder and Asperger's Disorder the best opportunity to master and successfully implement social/emotional skills.
\end{abstract}

Basic social deficits, often believed to be the most impaired ability in individuals with Autistic Disorder and Asperger's Disorder, range from an inability to gaze follow, which is typically established in the first few months of life (Johnson, 2000), to an inability to recognize emotions in others, an ability that is typically established in the first 5 years of life (Taylor, 1996). As a result, many studies have been dedicated to assessing exactly which social abilities are impaired in individuals with Autistic Disorder and Asperger's Disorder and which interventions may have the greatest impact on facilitating social interactions between these two groups of individuals and their typically-developed peers. Some of the social skills that have been addressed in the literature include joint attention (Pierce \& Schreibman, 1995), play skills (Harper, Symon, \& Frea, 2008), initiating dialogue (Chin \& Bernard-Opitz, 2000), and turn taking (Morrison, Kamps, Garcia, \& Parker, 2001). Of particular importance within this collection of skills is the social ability to recognize and understand emotions in others. This ability allows individuals to react to others in socially appropriate ways by reading nonverbal cues from facial expressions, body 
movements, and vocal expressions. This enables them to accurately assess the emotional state of their social interaction partners and respond appropriately.

This ability to recognize and understand emotions in others may be difficult to capture due to the fact that diagnosis may fall anywhere along the spectrum of Autism. Hence, a brief explanation of the diagnoses is necessary. Autistic Disorder differs from typical development in three specific areas: deficits in communication, socialization, and interests and activities (American Psychiatric Association, 2000). Another defining feature of Autistic Disorder is that 66-75\% of individuals demonstrate below-average intellectual abilities, specifically in terms of receiving scores of 70 or less on a standard IQ test (Heflin \& Alaimo, 2007). Additionally, while it is not necessary for the diagnosis of Autistic Disorder under the DSM-IV-TR, children with Autistic Disorder also typically demonstrate deficits in Theory of Mind (ToM): the inability to understand the emotions, beliefs, and behaviours of other people (Bell \& Kirby, 2002). Those classified as having high-functioning Autism generally display the same impairments as those with Autistic Disorder, with the exception that they do not have intelligence levels in the range of intellectual disabilities (Heflin \& Alaimo, 2007). Individuals with high-functioning Autism are not, however, to be considered the same as individuals with Asperger's Disorder. The primary and significant difference between high-functioning Autism and Asperger's Disorder is that individuals with high-functioning Autism demonstrate delays in language acquisition prior to age 3 as well as severe deficits in interests and activities, while individuals with Asperger's Disorder do not demonstrate these delays/deficits.

\section{The Research Dilemma}

A significant amount of research has been devoted to learning about the emotion abilities of individuals with Autistic Disorder and Asperger's Disorder, specifically attempting to determine what specific emotions offer the greatest level of difficulty for these individuals and if these individuals can learn to recognize and understand these emotions.

Overwhelming agreement amongst researchers has indicated that, at least in comparison to typically-developing peers, individuals with Autistic Disorder and Asperger's Disorder demonstrate weaker emotion recognition and understanding abilities. For instance, in Tager-Flusberg and Sullivan's (1995) hypothetical predictions study, participants with Autistic Disorder were presented with hypothetical scenarios that elicited particular emotions from story characters and were then asked to predict and explain the behaviour and emotions of those characters. The results indicated that participants with Autistic Disorder were found to give less emotional responses and explanations than typically-developed controls. Following suit, Golan, BaronCohen, and Golan (2008) and Golan, Baron-Cohen, and Hill (2006) looked at the emotion abilities of individuals with Autistic Disorder when presented with hypothetical scenarios and also found that they performed lower than the typical development control group on all presented emotion tasks. Individuals with Asperger's Disorder have also been found to struggle with emotion tasks. Lawson, Baron-Cohen, and Wheelwright (2004) asked participants to complete a questionnaire that consisted of a number of empathy items, at times paired with control items, to assess whether particular questions resulted in strong empathic responses. Lawson et al. (2004) noted that on empathic ability, participants with Asperger's Disorder did worse than both control groups in their study. Additionally, Silani et al. (2008) clearly noted a severe deficit in emotional-introspection awareness in Autistic Disorder and Asperger's Disorder participants. This result was determined by asking the participants to view a series of emotion-evoking pictures and to provide a self-reported degree of emotional awareness. 
The above select studies are reflective of a larger collection of studies that clearly indicate that under the broad category of socialization deficits, individuals with Autistic Disorder and Asperger's Disorder struggle with emotions. Given this, some researchers have taken this aspect of research a step further to determine exactly what emotion skills appear to be deficient in individuals with Autistic Disorder and/or Asperger's Disorder. Specifically, studies by Back, Ropar, and Mitchell (2007), Baron-Cohen, Wheelwright, and Jolliffe (1997), and Wallace, Coleman, and Bailey (2008) all found that individuals with Autistic Disorder and/or Asperger's Disorder performed significantly worse than their typically-developing peers in: (a) determining affect information as shown in the eyes versus the whole face; (b) labelling complex emotions when displayed through the eyes only; and (c) recognizing the emotion 'fear' from the eyes and 'disgust' from the mouth when presented with partial faces, respectively. On the contrary, Boraston, Blakemore, Chilvers, and Skuse (2007) and Humphreys, Minshew, Leonard, and Behrmann (2007) reported that individuals with Autistic Disorder scored as well as the control group when the emotions being depicted were 'scared' and 'disgust,' but they did significantly worse on all other emotions; participants with Autistic Disorder did as well as controls on recognizing emotions, except for the emotion of 'fear' which was often confused with 'surprise,' respectively. Generally speaking then, while the emotional impairments of individuals with Autistic Disorder and Asperger's Disorder appear to go beyond understanding specific emotions to include an inability to accurately recognize emotions displayed across several areas of the human body, the identification of deficits and/or abilities in specific emotions/skills produces mixed results.

It is not a surprise, therefore, that once sufficient research established that individuals with Autistic Disorder and Asperger's Disorder demonstrate emotional deficits, researchers would begin creating interventions to attempt to alleviate such deficits. Unfortunately, these interventions also produced mixed results. For instance, in Lacava, Golan, Baron-Cohen, and Myles' (2007) and Golan and Baron-Cohen's (2006) computer interventions it was found that face and voice emotion recognition for basic and complex emotions in individuals with Asperger's Disorder was improved, while Silver and Oakes (2001) reported that the experimental group with Asperger's Disorder outperformed the control group on all types of emotion questions presented. Conversely, Beaumont and Sofronoff (2008) reported less success with their intervention as they found that individuals with Asperger's Disorder performed as well as their wait-list control groups in recognizing facial expression and body-postures. With Bell and Kirby's (2002) ToM intervention, it was found that while participants with Autistic Disorder made progress in their comprehension of emotions, their individual results differed greatly from one another, and that while participants with Autistic Disorder could pass ToM tasks and maintain these skills months later, they did not generalize this ability to untaught domains (Hadwin, Baron-Cohen, Howlin, \& Hill, 1996). On the other hand, in Bernad-Ripoll's (2007) social story intervention the participant showed improvement in recognition and understanding of emotions within him and was even able to generalize these abilities to situations not explicitly taught in the videos and social stories. In Bauminger's (2002) social-emotional intervention study, individuals with Autistic Disorder progressed in all the domains examined and in the emotion domain specifically, participants: (a) provided more specific examples of when a particular emotion would arise; (b) provided a higher level of usage of complex emotions; and (c) often made a point of noting how the presence of an audience would impact the severity of an emotion.

Based on this limited review, there appear to be several notable inconsistencies that emanate from the reported results. For instance, there are inconsistencies between the effects of interventions, wherein social-emotional and social story interventions indicate a significant im- 
provement in emotion abilities, while ToM interventions provide varied results, suggesting that participants do not truly acquire an understanding about emotions post-intervention. Furthermore, computer intervention studies demonstrate within-intervention inconsistencies whereby three studies reported a significant increase in emotion ability, while another study showed levels of continued deficit in facial expression recognition.

Therefore, we deduced that the majority of the noted inconsistencies appeared to be due to non-specific skill deficit identification and/or poor matches between specific deficits and interventions. Applying an intervention without being aware of its potential drawbacks or pitfalls can further compound the existing deficits of participants. Potentially more problematic is the fact that these interventions are often the preferred platforms used to facilitate the participation of individuals with Autistic and Asperger's Disorders in inclusive classrooms; therefore, it stands to reason that interventions that do not accurately address their targeted deficits will interfere with their abilities to successfully socialize with peers.

The purpose of the current research synthesis, therefore, was to use a threefold analytic framework to analyze and compare extant emotion intervention studies. Specifically, any study that primarily attempted to improve the emotion recognition and understanding skills of individuals with Autistic Disorder and Asperger's Disorder was included in our analysis. These studies may have attempted to improve emotional recognition and understanding via: (a) explaining emotion characteristics; (b) identifying facial, bodily, and verbal cues of emotion; and (c) identifying appropriate use of emotions given external factors. This framework was comprised of three questions that sought to determine: (a) whether there were consistencies in specific skill deficit identifications for the two populations; (b) whether prescribed interventions were matched to specific skill deficits; and (c) whether interventions matched to specific skill deficits produced effective results.

\section{Method}

In order to be included in this synthesis, a study needed to meet the following criteria: (a) it must have used an intervention specifically designed to improve emotion recognition and understanding, as outlined above; (b) the intervention should be primarily targeted at improving emotion skills, as opposed to addressing emotion skills as a part of broader social skill interventions; (c) authors must have identified their participants as having Autistic Disorder or Asperger's Disorder; (d) the target of the study must have been the individual with Autistic Disorder or Asperger's Disorder, not their social interaction partners; (e) it must have been written in English; (f) it must have been published in a peer-reviewed journal; and ( $\mathrm{g}$ ) it must have been published between 1985 and 2010 (the year 1985 was selected as a starting point for the literature search because it was in this year that Baron-Cohen, Leslie, and Frith published the first study attempting to determine if children with Autism have a ToM, which is strongly related to the ability to understand emotions).

A multifaceted search was conducted to locate eligible studies. A detailed search was conducted by the first author in the PsycInfo, ERIC, and Medline databases using the search terms 'theor* of mind' OR 'mental state*' OR 'mindblindness' AND 'emot*' OR 'empath*' OR 'affect*' AND 'autis*' OR 'asperger*'. Each database was subjected to two searches: the first was a specific search using all of the above terms and, where applicable, using these search terms classified as 'keywords'; the second search was broader in scope whereby ToM search terms were excluded and, where applicable, the search terms were classified as 'anywhere.' This initial approach produced 24 studies that were eligible for the synthesis. Following this, the reference 
lists of those articles were examined to identify any additional articles that would be eligible for this study. Abstracts of references that were of interest were looked up and the same eligibility criteria were applied. After careful examination of the reference lists of the 24 selected articles, no additional studies were deemed eligible for this research synthesis.

At that point it was essential to review the keywords of the eligible articles to determine if any additional search-terms (outside of those already used in the search for existing literature) could be used to locate additional eligible studies. If additional search-words were obtained, the first author would conduct searches in each of the three databases mentioned above, together with a review of the reference lists of any eligible articles located. This process would occur in a cyclical fashion until no additional search-terms or articles could be added to this research synthesis. Upon inspection of the keywords specified in each of the 24 articles located, the following keywords commonly appeared across several articles: teaching, intervention, training, treatment, and social. In order to apply the search-terms 'teach*', 'interven*', 'train*', 'treat*', and 'social*', the first author would have to pair these terms with the search-terms 'autis*' and 'asperger*' in order to obtain intervention studies aimed at individuals with Autistic Disorder and/or Asperger's Disorder. Furthermore, the search-terms 'teach*', 'interven*', 'train*', 'treat*', and 'social*' would have also required pairing with the search-terms 'emot*', 'empath*', and 'affect*', so as to ensure that the intervention studies were attempting to improve the emotion abilities of individuals with Autistic Disorder and/or Asperger's Disorder. Therefore, the first author determined that the search-terms already used in the three databases provided a broader search than a search that would include the search-terms 'teach*', 'interven*', 'train*', 'treat*', and 'social*', and no further searching took place.

Finally, throughout the process of collecting eligible articles, the first author made note of the journals that published the eligible articles. Journals found to contribute multiple entries to this study were considered more likely to contain other studies eligible for this research. For the purposes of this research synthesis, multiple entries must have occurred by more than chance alone, and the first author felt that three or more articles would best fit this requirement. Therefore, the table of contents of journals producing three or more eligible articles were reviewed for additional eligible articles. The only journal to provide three or more eligible articles was the Journal of Autism and Developmental Disorders. The first author reviewed each issue from volumes 15 (1985) to 39 (2009) for eligible articles, making sure to strictly follow the eligibility criteria outlined above, but was unable to locate any additional articles for this study. Therefore, the final count for studies eligible for this research synthesis was 24 articles. The 24 studies analyzed in this synthesis are indicated in the reference section with an asterisk.

Table 1

Literature Search Results Emanating from PsycInfo, ERIC, and Medline, Total = 24

\begin{tabular}{cccc}
\hline & Search-term & Articles Produced & Eligible Articles \\
\hline Psyclnfo & Keyword & 133 & 7 \\
& Anywhere & 2572 & 12 \\
ERIC & All terms & 36 & 0 \\
& Emotion + Autism & 585 & 2 \\
\multirow{2}{*}{ Medline } & All terms & 132 & 1 \\
& Emotion + Autism & 2001 & 2 \\
\hline
\end{tabular}




\section{Analysis Procedures}

A descriptive synthesis approach was chosen for this research because social skill acquisition results are typically reported in the extant literature as binary yes/no nominal scores. Not having continuous scale scores does not lend an analysis to the quantitative measurement required for a statistical meta-analysis. Another reason for choosing the descriptive synthesis approach was that there were several noted methodological design differences between the 24 studies in that multiple baseline, case study, and repeated measures designs were all utilized. These design differences prevented the researchers from being able to conduct or extract effect sizes. Even if effect sizes were possible, this type of analysis would have resulted in too few studies within each of the design groups to conduct a valid meta-analysis. Finally, and most importantly, the descriptive synthesis approach allowed the researchers to more accurately capture the true essence of all of the semantically different variables used in the various approaches.

The following analytic framework questions were utilized to evaluate each of the 24 studies for potential inconsistencies. Each question is followed by a rationale for its inclusion as an evaluative criterion:

1(a) Did the study differentiate between the diagnoses of Autistic Disorder and Asperger's Disorder? The non-differentiation of Autistic Disorder from Asperger's Disorder is problematic because the DSM-IV diagnostic criteria for Autistic Disorder requires an indication of a cognitive deficit (IQ equal to or less than 85), which the Asperger's Disorder DSM-IV diagnosis does not require (American Psychiatric Association, 2000). The point here is that cognitive deficits can impair the ability to understand questions and/or formulate suitable responses;

(b) Were the diagnoses of each disorder confirmed (i.e., matched to DSM-IV criteria, provided by a psychiatrist/psychologist)? This is an important criterion as it would be unclear whether the categories of Autistic Disorder and/or Asperger's Disorder were designated properly and/or consistently within and across studies;

(c) Within studies that differentiated Autistic Disorder from Asperger's Disorder, was there further differentiation between low-functioning and high-functioning Autism? Because individuals with highfunctioning Autism do not have severe cognitive deficits (American Psychiatric Association, 2000), they will have a greater ability to understand the questions asked and to provide appropriate responses;

2(a) Did the prescribed intervention(s) match the diagnosed social skill deficits of the sample? In order to draw reliable conclusions from studies that examined both disorders, it is essential to ensure the intervention focused specifically on improving social skills via emotion recognition and/or understanding. Often times interventions attempt to address multiple skills that are known to be deficit in individuals with Autistic Disorder or Asperger's Disorder.

(b) In studies that included participants with Autistic Disorder, and specifically low-functioning Autism, were non-verbal response options offered? If researchers do not offer participants with Autistic Disorder an option to respond non-verbally, the results would likely be influenced by their lack of verbal abilities (Bell \& Kirby, 2002). In order for results about individuals with Autistic Disorder to be reliable, non-verbal response mechanisms, such as pressing specific buttons, should be offered as alternative response options.

(c) Were emotion lessons provided verbally (i.e., group discussions, scripts) and non-verbally (i.e., videotapes, computer games)? Individuals with both Autistic Disorder and Asperger's Disorder often demonstrate difficulty with non-verbal inferential messages (Bernad-Ripoll, 2007).

3(a) Did the study report improvements in emotional skills? If so, what specific skills? Although researchers often go to great efforts to create interventions that can potentially enhance specific social skill deficits, there is evidence, as noted above, that researchers fail to find consistent positive results despite using the same intervention. This may be due to inconsistent reporting of the same skills or the mislabelling of skills. 
(b) Did studies with prescribed and matched interventions report more improvements than studies that did not match interventions with sample deficit characteristics? A non-matched intervention is one that typically applies to a range of skills known to be deficit within these two disorders, but not the specific deficit skills of individual participants. It makes inherent sense that skill deficit-matched interventions would produce higher incidents and/or levels of improvement, but there is no evidence of the veracity of this assumption in the extant literature.

(c) Did the study report a generalization measure? If so, did the participant(s) show an ability to generalize? In terms of intervention emotion studies specifically, generalization refers to the ability to appropriately apply skills learned in context to social scenarios that were not explicitly taught/presented during the intervention.

For the purposes of this synthesis, basic emotions refer to the "fundamental emotions of 'happiness', 'sadness', 'anger', 'fear', 'surprise', and 'disgust', which are recognized crossculturally, while complex emotions refer to those emotions which involve attributing a cognitive state as well as an emotion" (Golan et al., 2008, p. 1534), for example 'disappointment,' 'relief,' 'jealousy,' and 'optimism.' Finally, emotion recognition can occur in three formats: facially, verbally, and bodily. For the purposes of this study, facial emotion recognition refers to how an emotion is displayed with the mouth and/or the eyes; verbal emotion recognition refers to how an emotion is depicted via words, sounds, and tone of voice; and emotion recognition through the body refers to how an emotion is expressed by pointing, gestures, and posture.

\section{Results}

Of the 24 studies collected for this synthesis, 12 (50\%) provided social/emotion interventions to individuals with Autistic Disorder, 4 (17\%) provided interventions to individuals with Asperger's Disorder, and $8(33 \%)$ provided interventions to individuals with both disorders. Nineteen of the 24 studies provided interventions to children while 5 provided interventions to adults with Autistic Disorder and/or Asperger's Disorder. Summaries of the articles included in the analysis with respect to the analytic framework criteria are included in the form of evidence tables.

\section{Inconsistencies in Emotion Interventions}

\section{Analytic framework question 1a: Did the study differentiate between the di- agnoses of Autistic Disorder and Asperger's Disorder? Given that interventions are} designed and implemented to address the diagnosed inabilities of participants, examining whether the categorizations of Autistic Disorder and/or Asperger's Disorder were used properly and/or consistently within and across studies is important because a failure to properly identify participants would likely interfere with the potential effects of the intervention. Regarding whether researchers took into account the inherent cognitive differences between participants with Autistic Disorder and those with Asperger's Disorder, none of the studies indicated differentiations between either the diagnoses or intervention implementations. This means that in terms of intervention, no less-cognitively demanding lessons were provided for those individuals with Autistic Disorder who, by definition, would be less cognitively able than participants with Asperger's Disorder (American Psychiatric Association, 2000). In regards to analysis, seven of the eight studies treated the combined participants as a homogenous group while only one study (Solomon, Goodlin-Jones, \& Anders, 2004) differentiated between the disorders. That particular study revealed no significant differences in skill acquisition after using a 2 x 2 analysis of variance with diagnosis as a between-subjects factor. Nonetheless, inconsistent and inaccurate 
Table 2

Evidence Tables Summarizing Studies According to Analytic Framework Criteria

\begin{tabular}{|c|c|c|c|c|}
\hline Study & $\begin{array}{c}\text { Participant } \\
\text { Characteristics }\end{array}$ & $\begin{array}{l}\text { Differentiation of } \\
\text { Intervention by } \\
\text { Disorders }\end{array}$ & Intervention Particulars & Reported Results \\
\hline $\begin{array}{l}\text { Argott, } \\
\text { Townsend, } \\
\text { Sturmey, \& } \\
\text { Poulson } \\
(2008)\end{array}$ & $\begin{array}{l}\text { Autistic Disorder; } \\
\text { Functioning level un- } \\
\text { known; } \\
\text { Confirmation of disor- } \\
\text { der by Psychia- } \\
\text { Psychia- } \\
\text { trist/Psychologist } \\
\text { notes }\end{array}$ & $\mathrm{n} / \mathrm{a}$ & $\begin{array}{l}\text { Matched to social skill deficit } \\
\text { only; } \\
\text { Non-verbal response mecha- } \\
\text { nism not offered; } \\
\text { Lessons were provided both } \\
\text { verbally and non-verbally; } \\
\text { Intervention was not matched } \\
\text { to the specific needs of the } \\
\text { participants }\end{array}$ & $\begin{array}{l}\text { Improvements post-intervention } \\
\text { were noted; } \\
\text { Emotion recognition via the face; } \\
\text { Emotion recognition via the body; } \\
\text { Emotion understanding of basic } \\
\text { emotions; } \\
\text { Generalization measures taken; } \\
\text { Generalization ability evident }\end{array}$ \\
\hline $\begin{array}{l}\text { Bauminger } \\
(2002)\end{array}$ & $\begin{array}{l}\text { Autistic Disorder; } \\
\text { High-functioning Au- } \\
\text { tism; } \\
\text { Confirmation of func- } \\
\text { tioning level by IQ; } \\
\text { Confirmation of diag- } \\
\text { nosis by DSM criteria, } \\
\text { other tests }\end{array}$ & $\mathrm{n} / \mathrm{a}$ & $\begin{array}{l}\text { Matched to social skill deficit } \\
\text { only; } \\
\text { Non-verbal response mecha- } \\
\text { nism not offered; } \\
\text { Lessons were provided ver- } \\
\text { bally; } \\
\text { Intervention was not matched } \\
\text { to the specific needs of the } \\
\text { participants }\end{array}$ & $\begin{array}{l}\text { Improvements post-intervention } \\
\text { were noted; } \\
\text { Emotion understanding of basic } \\
\text { emotions; } \\
\text { Emotion understanding of complex } \\
\text { emotions; } \\
\text { Emotion understanding via the inclu- } \\
\text { sion of an audience; } \\
\text { Emotion understanding via providing } \\
\text { examples; } \\
\text { Generalization measures not taken }\end{array}$ \\
\hline $\begin{array}{l}\text { Bauminger } \\
\text { (2007a) }\end{array}$ & $\begin{array}{l}\text { Autistic Disor- } \\
\text { der/Asperger's } \\
\text { Disorder; } \\
\text { High-functioning Au- } \\
\text { tism; } \\
\text { Confirmation of func- } \\
\text { tioning level by IQ; } \\
\text { Confirmation of disor- } \\
\text { der by DSM criteria, } \\
\text { Psychia- } \\
\text { trist/Psychologist } \\
\text { notes, other tests }\end{array}$ & $\begin{array}{l}\text { Intervention not } \\
\text { differentiated by } \\
\text { disorder; } \\
\text { Study data not } \\
\text { separated by } \\
\text { disorder }\end{array}$ & $\begin{array}{l}\text { Matched to social skill deficit } \\
\text { only; } \\
\text { Non-verbal response mecha- } \\
\text { nism not offered; } \\
\text { Lessons were provided ver- } \\
\text { bally; } \\
\text { Intervention was not matched } \\
\text { to the specific needs of the } \\
\text { participants }\end{array}$ & $\begin{array}{l}\text { Improvements post-intervention } \\
\text { were noted; } \\
\text { Emotion understanding of basic } \\
\text { emotions; } \\
\text { Emotion understanding of complex } \\
\text { emotions; } \\
\text { Emotion understanding via the inclu- } \\
\text { sion of an audience; } \\
\text { Emotion understanding via providing } \\
\text { justifications; } \\
\text { Emotion understanding via providing } \\
\text { examples; } \\
\text { Generalization measures not taken }\end{array}$ \\
\hline $\begin{array}{l}\text { Bauminger } \\
\text { (2007b) }\end{array}$ & $\begin{array}{l}\text { Autistic Disor- } \\
\text { der/Asperger's } \\
\text { Disorder; } \\
\text { High-functioning Au- } \\
\text { tism; } \\
\text { Confirmation of func- } \\
\text { tioning level by IQ; } \\
\text { Confirmation of disor- } \\
\text { der by DSM criteria, } \\
\text { Psychia- } \\
\text { trist/Psychologist } \\
\text { notes; other tests }\end{array}$ & $\begin{array}{l}\text { Intervention not } \\
\text { differentiated by } \\
\text { disorder; } \\
\text { Study data not } \\
\text { separated by } \\
\text { disorder }\end{array}$ & $\begin{array}{l}\text { Matched to social skill deficit } \\
\text { only; } \\
\text { Non-verbal response mecha- } \\
\text { nism not offered; } \\
\text { Lessons were provided ver- } \\
\text { bally; } \\
\text { Intervention was not matched } \\
\text { to the specific needs of the } \\
\text { participants }\end{array}$ & $\begin{array}{l}\text { Improvements post-intervention } \\
\text { were noted; } \\
\text { Emotion understanding of basic } \\
\text { emotions; } \\
\text { Emotion understanding of complex } \\
\text { emotions; } \\
\text { Emotion understanding via providing } \\
\text { justifications; } \\
\text { Emotion understanding via providing } \\
\text { examples; } \\
\text { Generalization measures not taken }\end{array}$ \\
\hline $\begin{array}{l}\text { Beaumont \& } \\
\text { Sofronoff } \\
(2008)\end{array}$ & $\begin{array}{l}\text { Asperger's Disorder; } \\
\text { Confirmation of disor- } \\
\text { der by other tests }\end{array}$ & $\mathrm{n} / \mathrm{a}$ & $\begin{array}{l}\text { Matched to social skill deficit } \\
\text { only; } \\
\text { Non-verbal response mecha- } \\
\text { nism not offered; } \\
\text { Lessons were provided both } \\
\text { verbally and non-verbally; } \\
\text { Intervention not matched to } \\
\text { specific needs of participants }\end{array}$ & $\begin{array}{l}\text { Improvements post-intervention } \\
\text { were noted; } \\
\text { Emotion recognition via the face; } \\
\text { Emotion recognition via the body; } \\
\text { Emotion understanding of basic } \\
\text { emotions; } \\
\text { Generalization measures not taken }\end{array}$ \\
\hline
\end{tabular}


Table 2 Cont'd

\begin{tabular}{|c|c|c|c|c|}
\hline Study & $\begin{array}{c}\text { Participant } \\
\text { Characteristics }\end{array}$ & $\begin{array}{l}\text { Differentiation of } \\
\text { Intervention by } \\
\text { Disorders }\end{array}$ & Intervention Particulars & Reported Results \\
\hline $\begin{array}{l}\text { Bell \& Kirby } \\
(2002)\end{array}$ & $\begin{array}{l}\text { Autistic Disorder; } \\
\text { Functioning level un- } \\
\text { known, } \\
\text { Confirmation of disor- } \\
\text { der by Psychia- } \\
\text { Psychia- } \\
\text { trist/Psychologist } \\
\text { notes, other tests }\end{array}$ & $\mathrm{n} / \mathrm{a}$ & $\begin{array}{l}\text { Matched to social skill deficit } \\
\text { only; } \\
\text { Non-verbal response mecha- } \\
\text { nism was offered; } \\
\text { Lessons were provided both } \\
\text { verbally and non-verbally; } \\
\text { Intervention was matched to } \\
\text { the specific needs of the par- } \\
\text { ticipants }\end{array}$ & $\begin{array}{l}\text { Improvements post-intervention } \\
\text { were noted; } \\
\text { Emotion recognition via the face; } \\
\text { Emotion understanding of basic } \\
\text { emotions; } \\
\text { Emotion understanding via providing } \\
\text { justifications; } \\
\text { Generalization measures taken; } \\
\text { Generalization ability not evident }\end{array}$ \\
\hline $\begin{array}{l}\text { Bernad- } \\
\text { Ripoll (2007) }\end{array}$ & $\begin{array}{l}\text { Asperger's Disorder; } \\
\text { Confirmation of disor- } \\
\text { der by DSM criteria, } \\
\text { Psychia- } \\
\text { trist/Psychologist } \\
\text { notes }\end{array}$ & $\mathrm{n} / \mathrm{a}$ & $\begin{array}{l}\text { Matched to social skill deficit } \\
\text { only; } \\
\text { Non-verbal response mecha- } \\
\text { nism not offered; } \\
\text { Lessons were provided both } \\
\text { verbally and non-verbally; } \\
\text { Intervention was matched to } \\
\text { the specific needs of the par- } \\
\text { ticipants }\end{array}$ & $\begin{array}{l}\text { Improvements post-intervention } \\
\text { were noted; } \\
\text { Emotion recognition via the face; } \\
\text { Emotion recognition via the body; } \\
\text { Emotion understanding of basic } \\
\text { emotions; } \\
\text { Emotion understanding of complex } \\
\text { emotions; } \\
\text { Emotion understanding via providing } \\
\text { justifications; } \\
\text { Emotion management; } \\
\text { Generalization measures taken; } \\
\text { Generalization ability evident }\end{array}$ \\
\hline $\begin{array}{l}\text { Bölte, } \\
\text { Feineis- } \\
\text { Matthews, } \\
\text { Leber, } \\
\text { Dierks, Hubl, } \\
\text { \& Poustka } \\
(2002)\end{array}$ & $\begin{array}{l}\text { Autistic Disor- } \\
\text { der/Asperger's } \\
\text { Disorder; } \\
\text { High-functioning Au- } \\
\text { tism; } \\
\text { No confirmation of } \\
\text { functioning level pro- } \\
\text { vided; } \\
\text { Confirmation of disor- } \\
\text { der by other tests }\end{array}$ & $\begin{array}{l}\text { Intervention not } \\
\text { differentiated by } \\
\text { disorder; } \\
\text { Study data not } \\
\text { separated by } \\
\text { disorder }\end{array}$ & $\begin{array}{l}\text { Matched to social skill deficit } \\
\text { only; } \\
\text { Non-verbal response mecha- } \\
\text { nism was offered; } \\
\text { Lessons were provided non- } \\
\text { verbally; } \\
\text { Intervention was not matched } \\
\text { to the specific needs of the } \\
\text { participants }\end{array}$ & $\begin{array}{l}\text { Improvements post-intervention } \\
\text { were noted; } \\
\text { Emotion recognition via the face; } \\
\text { Emotion understanding of basic } \\
\text { emotions; } \\
\text { Generalization measures not taken }\end{array}$ \\
\hline $\begin{array}{l}\text { Bölte, Hubl, } \\
\text { Feineis- } \\
\text { Matthews, } \\
\text { Prvulovic, } \\
\text { Dierks, \& } \\
\text { Poustka } \\
\text { (2006) }\end{array}$ & $\begin{array}{l}\text { Autistic Disorder; } \\
\text { High-functioning Au- } \\
\text { tism; } \\
\text { No confirmation of } \\
\text { functioning level pro- } \\
\text { vided; } \\
\text { Confirmation of disor- } \\
\text { der by other tests }\end{array}$ & $\mathrm{n} / \mathrm{a}$ & $\begin{array}{l}\text { Matched to social skill deficit } \\
\text { only; } \\
\text { Non-verbal response mecha- } \\
\text { nism was offered; } \\
\text { Lessons were provided non- } \\
\text { verbally; } \\
\text { Intervention was not matched } \\
\text { to the specific needs of the } \\
\text { participants }\end{array}$ & $\begin{array}{l}\text { Improvements post-intervention } \\
\text { were noted; } \\
\text { Emotion recognition via the face; } \\
\text { Emotion understanding of basic } \\
\text { emotions; } \\
\text { Generalization measures not taken }\end{array}$ \\
\hline $\begin{array}{l}\text { Feng, Lo, } \\
\text { Tsai, \& } \\
\text { Cartledge } \\
\text { (2008) }\end{array}$ & $\begin{array}{l}\text { Autistic Disorder; } \\
\text { Functioning level un- } \\
\text { known; } \\
\text { Confirmation of disor- } \\
\text { der by DSM criteria, } \\
\text { other tests }\end{array}$ & $\mathrm{n} / \mathrm{a}$ & $\begin{array}{l}\text { Matched to social skill deficit } \\
\text { only; } \\
\text { Non-verbal response mecha- } \\
\text { nism not offered; } \\
\text { Lessons were provided ver- } \\
\text { bally; } \\
\text { Intervention was matched to } \\
\text { the specific needs of the par- } \\
\text { ticipants }\end{array}$ & $\begin{array}{l}\text { Improvements post-intervention } \\
\text { were noted; } \\
\text { Emotion understanding of basic } \\
\text { emotions; } \\
\text { Emotion management; } \\
\text { Generalization measures taken; } \\
\text { Generalization ability evident }\end{array}$ \\
\hline
\end{tabular}


Table 2 Cont'd

\begin{tabular}{|c|c|c|c|c|}
\hline Study & $\begin{array}{c}\text { Participant } \\
\text { Characteristics }\end{array}$ & $\begin{array}{l}\text { Differentiation of } \\
\text { Intervention by } \\
\text { Disorders }\end{array}$ & Intervention Particulars & Reported Results \\
\hline $\begin{array}{l}\text { Golan \& } \\
\text { Baron- } \\
\text { Cohen } \\
(2006)\end{array}$ & $\begin{array}{l}\text { Autistic Disor- } \\
\text { der/Asperger's } \\
\text { Disorder; } \\
\text { High-functioning Au- } \\
\text { tism; } \\
\text { Confirmation of func- } \\
\text { tioning level by IQ; } \\
\text { Confirmation of disor- } \\
\text { der by DSM criteria, } \\
\text { other tests }\end{array}$ & $\begin{array}{l}\text { Intervention not } \\
\text { differentiated by } \\
\text { disorder; } \\
\text { Study data not } \\
\text { separated by } \\
\text { disorder }\end{array}$ & $\begin{array}{l}\text { Matched to social skill deficit } \\
\text { only; } \\
\text { Non-verbal response mecha- } \\
\text { nism was offered; } \\
\text { Lessons were provided both } \\
\text { verbally and non-verbally; } \\
\text { Intervention was not matched } \\
\text { to the specific needs of the } \\
\text { participants }\end{array}$ & $\begin{array}{l}\text { Improvements post-intervention } \\
\text { were noted; } \\
\text { Emotion recognition via the face; } \\
\text { Emotion recognition via the voice; } \\
\text { Emotion understanding of basic } \\
\text { emotions; } \\
\text { Emotion understanding of complex } \\
\text { emotions; } \\
\text { Generalization measures taken; } \\
\text { Generalization ability not evident }\end{array}$ \\
\hline $\begin{array}{l}\text { Hadwin, } \\
\text { Baron- } \\
\text { Cohen, } \\
\text { Howlin, \& } \\
\text { Hill (1996) }\end{array}$ & $\begin{array}{l}\text { Autistic Disorder; } \\
\text { Functioning level un- } \\
\text { known; } \\
\text { Confirmation of disor- } \\
\text { der by DSM criteria }\end{array}$ & $\mathrm{n} / \mathrm{a}$ & $\begin{array}{l}\text { Matched to social skill deficit } \\
\text { only; } \\
\text { It is unclear if a non-verbal } \\
\text { response mechanism was } \\
\text { offered; } \\
\text { Lessons were provided both } \\
\text { verbally and non-verbally; } \\
\text { Intervention was not matched } \\
\text { to the specific needs of the } \\
\text { participants }\end{array}$ & $\begin{array}{l}\text { Improvements post-intervention } \\
\text { were noted; } \\
\text { Emotion recognition via the face; } \\
\text { Emotion understanding of basic } \\
\text { emotions; } \\
\text { Generalization measures taken; } \\
\text { Generalization ability not evident }\end{array}$ \\
\hline $\begin{array}{l}\text { Hadwin, } \\
\text { Baron- } \\
\text { Cohen, } \\
\text { Howlin, \& } \\
\text { Hill (1997) }\end{array}$ & $\begin{array}{l}\text { Autistic Disorder; } \\
\text { Functioning level un- } \\
\text { known; } \\
\text { Confirmation of disor- } \\
\text { der by other tests }\end{array}$ & $\mathrm{n} / \mathrm{a}$ & $\begin{array}{l}\text { Matched to social skill deficit } \\
\text { only; } \\
\text { Non-verbal response mecha- } \\
\text { nism not offered; } \\
\text { Lessons were provided ver- } \\
\text { bally; } \\
\text { Intervention was not matched } \\
\text { to the specific needs of the } \\
\text { participants }\end{array}$ & $\begin{array}{l}\text { Improvements post-intervention } \\
\text { were noted; } \\
\text { Emotion recognition via the face; } \\
\text { Emotion understanding of basic } \\
\text { emotions; } \\
\text { Generalization measures not taken }\end{array}$ \\
\hline $\begin{array}{l}\text { Hillier, Fish, } \\
\text { Cloppert, \& } \\
\text { Beversdorf } \\
(2007)\end{array}$ & $\begin{array}{l}\text { Autistic Disor- } \\
\text { der/Asperger's } \\
\text { Disorder; } \\
\text { Functioning level un- } \\
\text { known; } \\
\text { Confirmation of disor- } \\
\text { der by other tests }\end{array}$ & $\begin{array}{l}\text { Intervention not } \\
\text { differentiated by } \\
\text { disorder; } \\
\text { Study data not } \\
\text { separated by } \\
\text { disorder }\end{array}$ & $\begin{array}{l}\text { Not matched to social skill } \\
\text { deficit only; } \\
\text { Non-verbal response mecha- } \\
\text { nism not offered; } \\
\text { Lessons were provided ver- } \\
\text { bally; } \\
\text { Intervention was not matched } \\
\text { to the specific needs of the } \\
\text { participants }\end{array}$ & $\begin{array}{l}\text { Improvements post-intervention } \\
\text { were noted; } \\
\text { Emotion understanding via providing } \\
\text { examples; } \\
\text { Generalization measures not taken }\end{array}$ \\
\hline $\begin{array}{l}\text { Katagiri } \\
(2009)\end{array}$ & $\begin{array}{l}\text { Autistic Disorder; } \\
\text { Functioning level un- } \\
\text { known; } \\
\text { No confirmation of } \\
\text { disorder reported }\end{array}$ & $\mathrm{n} / \mathrm{a}$ & $\begin{array}{l}\text { Matched to social skill deficit } \\
\text { only; } \\
\text { Non-verbal response mecha- } \\
\text { nism not offered; } \\
\text { Lessons were provided ver- } \\
\text { bally; } \\
\text { Intervention was not matched } \\
\text { to the specific needs of the } \\
\text { participants }\end{array}$ & $\begin{array}{l}\text { Improvements post-intervention } \\
\text { were noted; } \\
\text { Emotion recognition via the face; } \\
\text { Emotion understanding of basic } \\
\text { emotions; } \\
\text { Generalization measures not taken }\end{array}$ \\
\hline
\end{tabular}




\section{Table 2 Cont'd}

\begin{tabular}{|c|c|c|c|c|}
\hline Study & $\begin{array}{c}\text { Participant } \\
\text { Characteristics }\end{array}$ & $\begin{array}{l}\text { Differentiation of } \\
\text { Intervention by } \\
\text { Disorders }\end{array}$ & Intervention Particulars & Reported Results \\
\hline $\begin{array}{l}\text { Lacava, } \\
\text { Golan, } \\
\text { Baron- } \\
\text { Cohen, \& } \\
\text { Myles } \\
(2007)\end{array}$ & $\begin{array}{l}\text { Asperger's Disorder; } \\
\text { Confirmation of disor- } \\
\text { der by DSM criteria, } \\
\text { Psychia- } \\
\text { trist/Psychologist } \\
\text { notes, other tests }\end{array}$ & $\mathrm{n} / \mathrm{a}$ & $\begin{array}{l}\text { Matched to social skill deficit } \\
\text { only; } \\
\text { Non-verbal response mecha- } \\
\text { nism was offered; } \\
\text { Lessons were provided non- } \\
\text { verbally; } \\
\text { Intervention was not matched } \\
\text { to the specific needs of the } \\
\text { participants }\end{array}$ & $\begin{array}{l}\text { Improvements post-intervention } \\
\text { were noted; } \\
\text { Emotion recognition via the face; } \\
\text { Emotion recognition via the voice; } \\
\text { Emotion understanding of basic } \\
\text { emotions; } \\
\text { Emotion understanding of complex } \\
\text { emotions; } \\
\text { Generalization measures not taken }\end{array}$ \\
\hline $\begin{array}{l}\text { Lopata, } \\
\text { Thomeer, } \\
\text { Volker, } \\
\text { Nida,\& Lee } \\
(2008)\end{array}$ & $\begin{array}{l}\text { Autistic Disor- } \\
\text { der/Asperger's } \\
\text { Disorder; } \\
\text { High-functioning level; } \\
\text { Confirmation of func- } \\
\text { tioning level by IQ; } \\
\text { Confirmation of disor- } \\
\text { der by DSM criteria, } \\
\text { Psychia- } \\
\text { trist/Psychologist } \\
\text { notes, other tests }\end{array}$ & $\begin{array}{l}\text { Intervention not } \\
\text { differentiated by } \\
\text { disorder; } \\
\text { Study data not } \\
\text { separated by } \\
\text { disorder }\end{array}$ & $\begin{array}{l}\text { Matched to social skill deficit } \\
\text { only; } \\
\text { Non-verbal response mecha- } \\
\text { nism was offered; } \\
\text { Lessons were provided both } \\
\text { verbally and non-verbally; } \\
\text { Intervention was not matched } \\
\text { to the specific needs of the } \\
\text { participants }\end{array}$ & $\begin{array}{l}\text { No Improvements post-intervention } \\
\text { were noted; } \\
\text { Generalization measures not taken }\end{array}$ \\
\hline $\begin{array}{l}\text { Schrandt, } \\
\text { Townsend, } \\
\text { \& Poulson } \\
\text { (2009) }\end{array}$ & $\begin{array}{l}\text { Autistic Disorder; } \\
\text { Functioning level un- } \\
\text { known; } \\
\text { Confirmation of disor- } \\
\text { der by other tests }\end{array}$ & $\mathrm{n} / \mathrm{a}$ & $\begin{array}{l}\text { Matched to social skill deficit } \\
\text { only; } \\
\text { Non-verbal response mecha- } \\
\text { nism not offered; } \\
\text { Lessons were provided both } \\
\text { verbally and non-verbally; } \\
\text { Intervention was not matched } \\
\text { to the specific needs of the } \\
\text { participants }\end{array}$ & $\begin{array}{l}\text { Improvements post-intervention } \\
\text { were noted; } \\
\text { Emotion recognition via the face; } \\
\text { Emotion recognition via the voice; } \\
\text { Emotion understanding of basic } \\
\text { emotions; } \\
\text { Generalization measures taken; } \\
\text { Generalization ability evident }\end{array}$ \\
\hline $\begin{array}{l}\text { Silver \& } \\
\text { Oakes } \\
(2001)\end{array}$ & $\begin{array}{l}\text { Autistic Disor- } \\
\text { der/Asperger's } \\
\text { Disorder; } \\
\text { Functioning level un- } \\
\text { known; } \\
\text { No confirmation of } \\
\text { disorder reported }\end{array}$ & $\begin{array}{l}\text { Intervention not } \\
\text { differentiated by } \\
\text { disorder; } \\
\text { Study data not } \\
\text { separated by } \\
\text { disorder }\end{array}$ & $\begin{array}{l}\text { Matched to social skill deficit } \\
\text { only; } \\
\text { Non-verbal response mecha- } \\
\text { nism was offered; } \\
\text { Lessons were provided non- } \\
\text { verbally; } \\
\text { Intervention was not matched } \\
\text { to the specific needs of the } \\
\text { participants }\end{array}$ & $\begin{array}{l}\text { Improvements post-intervention } \\
\text { were noted; } \\
\text { Emotion recognition via the face; } \\
\text { Emotion understanding of basic } \\
\text { emotions; } \\
\text { Emotion understanding via providing } \\
\text { justifications; } \\
\text { Generalization measures not taken }\end{array}$ \\
\hline $\begin{array}{l}\text { Sofronoff, } \\
\text { Attwood, } \\
\text { Hinton, \& } \\
\text { Levin } \\
\text { (2007) }\end{array}$ & $\begin{array}{l}\text { Asperger's Disorder; } \\
\text { Confirmation of disor- } \\
\text { der by DSM criteria, } \\
\text { other tests }\end{array}$ & $\mathrm{n} / \mathrm{a}$ & $\begin{array}{l}\text { Matched to social skill deficit } \\
\text { only; } \\
\text { Non-verbal response mecha- } \\
\text { nism was offered; } \\
\text { Lessons were provided both } \\
\text { verbally and non-verbally; } \\
\text { Intervention was not matched } \\
\text { to the specific needs of the } \\
\text { participants }\end{array}$ & $\begin{array}{l}\text { Improvements post-intervention } \\
\text { were noted; } \\
\text { Emotion management; } \\
\text { Generalization measures taken; } \\
\text { Generalization ability evident }\end{array}$ \\
\hline
\end{tabular}


Table 2 Cont'd

\begin{tabular}{|c|c|c|c|c|}
\hline Study & $\begin{array}{c}\text { Participant } \\
\text { Characteristics }\end{array}$ & $\begin{array}{l}\text { Differentiation of } \\
\text { Intervention by } \\
\text { Disorders }\end{array}$ & Intervention Particulars & Reported Results \\
\hline $\begin{array}{l}\text { Solomon, } \\
\text { Goodlin- } \\
\text { Jones, \& } \\
\text { Anders } \\
(2004)\end{array}$ & $\begin{array}{l}\text { Autistic Disor- } \\
\text { der/Asperger's } \\
\text { Disorder; } \\
\text { High-functioning Au- } \\
\text { tism; } \\
\text { Confirmation of func- } \\
\text { tioning level by IQ; } \\
\text { Confirmation of disor- } \\
\text { der by DSM criteria, } \\
\text { other tests }\end{array}$ & $\begin{array}{l}\text { Intervention not } \\
\text { differentiated by } \\
\text { disorder; } \\
\text { Study data ana- } \\
\text { lyzed separately }\end{array}$ & $\begin{array}{l}\text { Matched to social skill deficit } \\
\text { only; } \\
\text { Non-verbal response mecha- } \\
\text { nism not offered; } \\
\text { Lessons were provided both } \\
\text { verbally and non-verbally; } \\
\text { Intervention was not matched } \\
\text { to the specific needs of the } \\
\text { participants }\end{array}$ & $\begin{array}{l}\text { Improvements post-intervention } \\
\text { were noted; } \\
\text { Emotion recognition via the face; } \\
\text { Emotion understanding of basic } \\
\text { emotions; } \\
\text { Generalization measures not taken }\end{array}$ \\
\hline $\begin{array}{l}\text { Stafford } \\
(2000)\end{array}$ & $\begin{array}{l}\text { Autistic Disorder; } \\
\text { Low-functioning Au- } \\
\text { tism; } \\
\text { Confirmation of func- } \\
\text { tioning level by life- } \\
\text { skill assessment; } \\
\text { No confirmation of } \\
\text { disorder reported }\end{array}$ & $\mathrm{n} / \mathrm{a}$ & $\begin{array}{l}\text { Matched to social skill deficit } \\
\text { only; } \\
\text { Non-verbal response mecha- } \\
\text { nism was offered; } \\
\text { Lessons were provided both } \\
\text { verbally and non-verbally; } \\
\text { Intervention was matched to } \\
\text { the specific needs of the par- } \\
\text { ticipants }\end{array}$ & $\begin{array}{l}\text { Improvements post-intervention } \\
\text { were noted; } \\
\text { Emotion recognition via the face; } \\
\text { Emotion understanding of basic } \\
\text { emotions; } \\
\text { Generalization measures not taken }\end{array}$ \\
\hline $\begin{array}{l}\text { Turner- } \\
\text { Brown, } \\
\text { Perry, } \\
\text { Dichter, } \\
\text { Bodfish, \& } \\
\text { Penn (2008) }\end{array}$ & $\begin{array}{l}\text { Autistic Disorder; } \\
\text { High-functioning Au- } \\
\text { tism; } \\
\text { No confirmation of } \\
\text { functioning level pro- } \\
\text { vided; } \\
\text { Confirmation of disor- } \\
\text { der by Psychia- } \\
\text { Psychia- } \\
\text { trist/Psychologist } \\
\text { notes, other tests }\end{array}$ & $\mathrm{n} / \mathrm{a}$ & $\begin{array}{l}\text { Matched to social skill deficit } \\
\text { only; } \\
\text { Non-verbal response mecha- } \\
\text { nism not offered; } \\
\text { Lessons were provided both } \\
\text { verbally and non-verbally; } \\
\text { Intervention was not matched } \\
\text { to the specific needs of the } \\
\text { participants }\end{array}$ & $\begin{array}{l}\text { Improvements post-intervention } \\
\text { were noted; } \\
\text { Emotion recognition via the face; } \\
\text { Emotion understanding of basic } \\
\text { emotions; } \\
\text { Generalization measures not taken }\end{array}$ \\
\hline $\begin{array}{l}\text { Yang, } \\
\text { Schaller, } \\
\text { Huang, } \\
\text { Wang, \& } \\
\text { Tsai (2003) }\end{array}$ & $\begin{array}{l}\text { Autistic Disorder; } \\
\text { Low-functioning Au- } \\
\text { tism; } \\
\text { Confirmation of func- } \\
\text { tioning level by IQ; } \\
\text { Confirmation of disor- } \\
\text { der by Psychia- } \\
\text { Psychia- } \\
\text { trist/Psychologist } \\
\text { notes, other tests }\end{array}$ & $\mathrm{n} / \mathrm{a}$ & $\begin{array}{l}\text { Matched to social skill deficit } \\
\text { only; } \\
\text { Non-verbal response mecha- } \\
\text { nism was offered; } \\
\text { Lessons were provided ver- } \\
\text { bally; } \\
\text { Intervention was not matched } \\
\text { to the specific needs of the } \\
\text { participants }\end{array}$ & $\begin{array}{l}\text { Improvements post-intervention } \\
\text { were noted; } \\
\text { Emotion recognition via the face; } \\
\text { Emotion understanding of basic } \\
\text { emotions; } \\
\text { Generalization measures not taken }\end{array}$ \\
\hline
\end{tabular}

conclusions may be drawn from these eight studies because the likely poorer performances of individuals with Autistic Disorder would be obscured when the intervention scores of both groups were summed.

\footnotetext{
Analytic framework question $1 \mathrm{~b}$ : Were the diagnoses of each disorder confirmed (i.e., matched to DSM-IV criteria, provided by a psychiatrist or psychologist)? It is worthwhile to note that 21 out of 24 studies $(87.5 \%)$ confirmed the diagnoses of their participants by using either DSM-IV criteria, a professionally rendered diagnosis, or a variety of test-battery results, while 3 studies (Katagiri, 2009; Silver \& Oakes, 2001; Stafford, 2000) did not explain how participant diagnoses were attributed. In fact, 13 studies used more than one method of confirmation by pairing two or more of the above criteria. It does not appear that inconsistencies would result from invalid participant diagnoses; however, the results
} 
from the three studies that did not confirm participant diagnoses must be interpreted with caution as these diagnoses could have been derived from less rigorous/objective evidence.

Analytic framework question 1c: Within studies that differentiated Autistic Disorder from Asperger's Disorder, was there further differentiation between lowfunctioning and high-functioning Autism? Not differentiating between low-functioning and high-functioning Autism is of concern because differences in their respective cognitive abilities would be sufficient to skew obtained results. Nine studies did not differentiate the functioning levels of participants. Of the 11 studies that did differentiate functioning levels, 2 provided interventions to individuals with low-functioning Autism and 10 provided interventions to individuals with high-functioning Autism (1 study provided an intervention to participants with low-functioning and high-functioning Autism, and is therefore counted twice). It is highly problematic therefore, that $45 \%$ of the reported studies provided interventions to groups of individuals with Autistic Disorder without fully describing the capabilities and the deficits of the participants. It is extremely possible that had the functioning levels of participants been known and the interventions been tailored to suit functioning levels, the researchers would have obtained even stronger results.

The manner by which functioning level was determined was also analyzed. Seven studies indicated that cognitive functioning levels were obtained via cut-off scores on intelligence scales, one study (Stafford, 2000) described the determination of functioning level as the participant not demonstrating life skills or verbal abilities, and three studies (Bölte et al., 2002; Bölte et al., 2006; Turner-Brown, Perry, Dichter, Bodfish, \& Penn, 2008) did not indicate how functioning levels were determined. Inconsistencies are likely to be drawn from these results by readers as $27 \%$ of the studies that provided functioning levels failed to indicate how these were determined. Similar to the potential non-use of rigorous criteria to determine the proper diagnoses of participants described above, functioning levels could also be based on subjective criteria, thus, the results of these particular studies should be interpreted with considerable caution. It appears quite likely that intervention results would be inconsistently interpreted because numerous studies did not fully explain the cognitive functioning levels of participants.

Analytic framework question 2a: Did the prescribed intervention(s) match the diagnosed social skill deficits of the sample? Matching interventions to social skill deficits of the groups is important as comparisons between study results can only be confidently made across skills that are shared deficits. Our analysis revealed that 23 of the studies (96\%) attempted to correct socialization skills only, while 1 study (Hillier, Fish, Cloppert, \& Beversdorf, 2007) attempted to correct both social and vocational skills related to social interaction within the same intervention. It does not appear that inconsistencies would result because of a mismatch between interventions and social skill deficits.

Table 3

Differentiation Between Autistic Disorder Functioning Level

\begin{tabular}{|c|c|c|c|c|c|c|}
\hline \multirow[b]{2}{*}{ Participants } & \multicolumn{3}{|c|}{ Functioning Level } & \multicolumn{3}{|c|}{ Confirmation of Functioning Level } \\
\hline & $\mathrm{LFA}^{\mathrm{a}}$ & $\mathrm{HFA}^{\mathrm{b}}$ & Unclear & $\mathrm{IQ}^{\mathrm{c}}$ & Other $^{d}$ & Not Confirmed \\
\hline Autistic Disorder & 2 & 4 & 7 & 2 & 1 & 2 \\
\hline Combined group & 0 & 6 & 2 & 5 & 0 & 1 \\
\hline
\end{tabular}


Analytic framework question $2 b$ : In studies that included participants with Autistic Disorder, and specifically low-functioning Autism, were non-verbal response options offered? Regarding whether non-verbal response mechanisms were offered to participants, it is important to note that failing to provide non-verbal response options to individuals with Autistic Disorder would probably drastically reduce the success rates of interventions due to the inherent verbal deficits of this group (American Psychiatric Association, 2000). As can be seen in Table 4, only eight studies offered non-verbal response options to the Autistic Disorder or Combined groups. More worrisome is the fact that only 4 of the 12 studies specific to individuals with Autistic Disorder offered non-verbal response mechanisms. One study (Hadwin et al., 1996) did not indicate how emotion skills were assessed. The potential inconsistency of interpretation resulting from this issue is clear: 7 of 12 Autistic Disorder studies and 4 of 8 Combined groups studies (55\%) could have provided non-verbal response mechanisms to participants with Autistic Disorder who clearly could have benefited from this option. As well, it is likely that the failure to take the language abilities of the participants into account resulted in scores that may have been well below what would have been obtained had individuals with Autistic Disorder been able to provide their responses in verbal or non-verbal form.

Analytic framework question 2c: Were emotion lessons provided verbally (i.e., group discussions, scripts) and non-verbally (i.e., videotapes, computer games)? Continuing this line of thought, it is obvious that individuals with Autistic Disorder and Asperger's Disorder can greatly benefit from both verbal and non-verbal lessons as they have considerable difficulty with non-verbal messages, as was previously noted. As can be seen in Table 5, 7 of 24 studies (29\%) provided emotion lessons in verbal form only, only 4 studies (17\%) provided non-verbal emotion lessons, and the majority of studies $(13,54 \%)$ provided emotion lessons in both formats. For the four studies that failed to take into account the crucial and inherent difficulty these participants have with non-verbal messages, it is a reasonable assumption that the intervention messages were most likely poorly interpreted and responded to in comparison to studies that offered lessons in both forms. This would quite likely have produced lower scores post-intervention and it calls the results of such studies into question.

Table 4

Non-Verbal Response Mechanisms Offered

\begin{tabular}{lccc}
\hline \multicolumn{1}{c}{ Participants } & Yes & No & Unclear \\
\hline Autistic Disorder & 4 & 7 & 1 \\
Asperger's Disorder & 2 & 2 & 0 \\
Combined group & 4 & 4 & 0 \\
\hline
\end{tabular}

Table 5

Manner by Which Emotion Lessons Were Provided

\begin{tabular}{lccc}
\hline \multicolumn{1}{c}{ Participants } & Verbally & Non-verbally & Both \\
\hline Autistic Disorder & 4 & 1 & 7 \\
Asperger's Disorder & 0 & 1 & 3 \\
Combined group & 3 & 2 & 3 \\
\hline
\end{tabular}


Analytic framework question 3a: Did the study report improvements in emotional skills? If so, what specific skills? In order for researchers and educators to make valid conclusions about participants' abilities and the effectiveness of emotion skill interventions, studies should report results about similar variables or provide clear justifications why obviously different variables or methods were used. Unless these differentiations are made clear, the opportunity for misinterpretation is high. This research synthesis examined the three prevalent skill categories of emotion recognition, emotion understanding, and emotion management. Emotion recognition refers to the ability of participants to correctly label emotions based on the information provided via the face, bodily movements, or through vocal messages. Emotion understanding refers to the ability of participants to provide advanced explanations of emotions such as the characteristics of an emotion, how the presence of others impacted on emotions, and what situations lead to an individual experiencing emotion. Emotion management refers to the ability of participants to control their emotional expressions.

As evident in Table 6, 23 of 24 studies (96\%) indicated varying levels of emotion skill improvement post-intervention with only the Lopata, Thomeer, Volker, Nida, and Lee (2008) study indicating no improvement. Although the Beaumont and Safronoff (2008) study indicated improved emotion skills, the control group performed as well as the experimental group postintervention and 21 studies indicated improved skills in more than one skill category. Researchers and educators should be aware, however, that inconsistencies can result from an improper interpretation of the results of these studies. For example, while $70 \%$ of the examined studies noted improvements in emotion recognition via the face and $78 \%$ noted improvements in emotion understanding via basic emotions, the other emotion recognition and emotion understanding options topped off at $14 \%$ and $17 \%$, respectively. Therefore, while on the surface it may appear that 23 of the 24 studies reported improvements in emotion skills post-intervention, these improvements were limited to facial emotion recognition and understanding of basic emotions. This finding is a considerable limitation for educators who choose to use the interventions employed in these studies to improve more complex skills such as advanced emotion understandings and/or emotion management.

\section{Analytic framework question $3 \mathrm{~b}$ : Did studies with prescribed and matched interventions report more improvements than studies that did not match interven- tions with sample deficit characteristics? Matching interventions to the specific needs of participants requires significant effort and can potentially provide considerable benefits. If matched interventions do not provide high rates of success, researchers will have little reason to use them over broad-based interventions. The results revealed that only 4 of 24 studies (17\%)}

Table 6

Reported Improvements in Emotional Skills

\begin{tabular}{|c|c|c|c|c|c|c|c|c|c|c|c|}
\hline \multirow[b]{2}{*}{ Participants } & \multicolumn{2}{|c|}{$\begin{array}{l}\text { Improved } \\
\text { Skills }\end{array}$} & \multicolumn{3}{|c|}{ Emotion Recognition } & \multicolumn{5}{|c|}{ Emotion Understanding } & \multirow[t]{2}{*}{$\begin{array}{c}\text { Emotion } \\
\text { Management }\end{array}$} \\
\hline & Yes & No & Face & Body & Voice & Basic $^{a}$ & Complex $^{b}$ & Audience $^{c}$ & Justification $^{d}$ & Example $^{e}$ & \\
\hline $\begin{array}{l}\text { Autistic } \\
\text { Disorder }\end{array}$ & 12 & 0 & 9 & 1 & 1 & 9 & 1 & 1 & 1 & 1 & 1 \\
\hline $\begin{array}{l}\text { Asperger's } \\
\text { Disorder }\end{array}$ & 4 & 0 & 3 & 2 & 1 & 3 & 2 & 0 & 1 & 0 & 2 \\
\hline $\begin{array}{l}\text { Combined } \\
\text { group }\end{array}$ & 7 & 1 & 4 & 0 & 1 & 6 & 3 & 1 & 3 & 3 & 0 \\
\hline
\end{tabular}


provided interventions that were specifically matched to the needs of participants. The remaining 20 studies $(83 \%)$ offered broad-based interventions across participant pools. All four studies that offered matched interventions found improvements in emotion skills post-intervention. Therefore, when compared to the data reported in Table 6, it would appear that matched interventions provide similar high rates of improvements as non-matched interventions $(100 \%$ and $95 \%$, respectively). Thus, it does not appear that inconsistencies can result from providing matched versus non-matched interventions. Based on this evidence, educators would be able to save the time, effort, and costs associated with matching interventions with specific skill deficits.

\section{Analytic framework question 3c: Did the study report a generalization meas- ure? If so, did the participant(s) show an ability to generalize? Determining whether} generalization measures were obtained and whether participants were able to successfully generalize their knowledge to novel scenarios is of significant importance. If researchers are unable to demonstrate/report generalization, then no firm conclusions can be drawn about the true levels of emotion understandings of participants or of an intervention's efficacy in teaching new skills to be used in everyday life. This research synthesis found that only eight of the reviewed studies $(33 \%)$ measured generalization skills and of those, only five reported that participants could apply their new knowledge to similar, yet novel, scenarios. This synthesis criterion reveals a major inconsistency in that $67 \%$ of the studies failed to determine whether their participants actually learned from their emotion lessons. A further evaluation of the studies that did measure generalization revealed that none of the eight studies indicated whether the intervention specifically taught participants how to generalize emotion skills. This is of significance because as Matson and Swiezy (1994) so adroitly pointed out, "generalization does not occur naturally but must be programmed into the treatment process" (p. 252). It is highly probable, then, that participants were able to generalize their skills to new, yet similar, scenarios because they followed intervention scripts that drew connections between " $x$ " attribute and " $y$ " emotion. If they were not explicitly taught how to apply their new skill to other dissimilar emotions, it is questionable whether they would be able to make the connections on their own and thus would not perform as well on other generalization measures.

\section{Discussion}

Based on initial evidence that suggested the potential for inconsistencies in interpreting emotion skill intervention outcomes, this research sought to determine whether actual inconsistencies were evident throughout the body of relevant literature. As was demonstrated in the 24 studies examined, several potential inconsistencies exist that call into question the positive results reported. Inconsistencies occurred in two principal areas across the 24 studies examined. First, answers to six of our nine analytic questions resulted in either an obvious inconsistency or results that allude to the potential for inconsistent interpretations. This was a somewhat problematic finding considering $96 \%$ of the studies had reported improved emotion skills postintervention. One would like to feel more assured about a preponderance of seemingly beneficial findings. Unfortunately, it is likely that these inconsistencies led to incorrect reporting of the skills obtained via the interventions, thus resulting in the reported high success rates of the interventions. It also appears likely that non-success rates were also incorrectly reported. For example, had the combined group studies treated the two groups separately, it is highly probable that the researchers would have found that groups with Asperger's Disorder performed significantly better than groups with Autistic Disorder. Rather, as was previously hypothesized, it is not 
inconceivable that the combined scores of the two groups provided both a poorer understanding of the abilities of individuals with Asperger's Disorder and an inflated representation of the abilities of individuals with Autistic Disorder.

Second, of the predominant inconsistencies noted there were five predominant types specifically related to: (a) participant categorization; (b) participant cognitive functioning levels; (c) accounting for language deficits; (d) the potential for incorrect interpretations of reported results; and (e) generalization measures.

The manner by which researchers determined the diagnoses of participants sets valid studies apart from invalid studies. Specifically, had the diagnoses been confirmed using the rigorous criteria available for each disorder, the interventions utilized could have been better justified and the results obtained would have been more valid. Taken together, then, the results from such studies would strengthen the validity of the entire body of literature on emotion interventions for both disorders.

Failure to obtain/report cognitive functioning levels for participants with Autistic Disorder contributed to inconsistent results. Because the functioning level of participants was unknown, it could be construed that: (a) the intervention was too easy and was essentially measuring skills within the participants' abilities or (b) the intervention did address actual deficit skills and the intervention truly obtained the positive results reported. Had the researchers confirmed the functioning levels of participants, stronger and more concrete conclusions could be made regarding the effectiveness of those particular interventions.

The fact that language deficits were unaccounted for in the interventions contributed to significant inconsistencies. Had non-verbal response mechanisms been provided and had emotion lessons been provided both verbally and non-verbally on a more consistent basis, the extent of emotional deficits and potential improvements could have been more deeply examined because inherent language ability deficits would have been controlled for.

Although $96 \%$ of the studies reviewed here concluded that the implemented intervention provided improved emotion skills for individuals with Autistic Disorder and Asperger's Disorder, it is imperative to note that these improvements are restricted and can in no way be considered indicative of our overall understandings about the efficacy of emotion skill interventions. This is an extremely important consideration because such misperceptions will lead researchers to incorrect assumptions that will act as the basis for their own use or non-use of particular interventions. For instance, with regards to the intervention developed by Silver and Oakes (2001), Bölte et al. (2006) reported that it "improved facial affect understanding in autism" (p. 211), while Lacava et al. (2007) reported that it improved participants' abilities "to identify emotions in story and cartooned situations that triggered an emotional response, but not their recognition of emotion in photographed facial expressions" (p. 175). These are two different types and levels of emotion skill improvements and it is an example of how failing to accurately and specifically indicate skill results can provide an erroneous basis for future uses of an intervention.

Finally, failing to build generalization measures into interventions also contributes to inconsistencies in interpreting results. Specifically, had researchers built generalization measures into their interventions, they would have been able to better examine and explain the effectiveness of the interventions. As it stands, practitioners, educators, and parents have no assurance that applications of these interventions will be effective in the various settings in which the child functions. 


\section{Conclusion}

The discipline of Autism-specific research is in a state of flux and development and this is especially true in terms of the design and implementation of social and emotion skill interventions. While several noteworthy inconsistencies were found within the studies reviewed, 23 studies reported emotion skill improvements, even if some of these improvements were modest. What can be assumed as a general consensus, therefore, is that emotion skill interventions appear to offer individuals with Autistic Disorder and Asperger's Disorder the opportunity to improve upon social deficits but that more rigorous, research is needed so that educators can use interventions with confidence.

Due to our initial noted discrepancies, our analytic framework questions pertained to the diagnostic categories of the participants and the implications of such on the methods and results of the examined studies. It is possible, however, that other inconsistencies may have been revealed had other factors, such as length of intervention, the types of measurements used to collect data, and the calculation of effect sizes, been scrutinized. On the other hand, it would not be difficult or onerous for researchers to correct for the above-noted inconsistencies so as to provide better evidence about the efficacy of emotion skill interventions.

\section{References}

American Psychiatric Association. (2000). Diagnostic and statistical manual of mental disorders (4th ed., text revision). Washington, DC: Author.

*Argott, P., Townsend, D. B., Sturmey, P., \& Poulson, C. L. (2008). Increasing the use of empathic statements in the presence of a non-verbal affective stimulus in adolescents with autism. Research in Autism Spectrum Disorders, 2, 341-352. doi:10.1016/j.rasd.2007.08.004

Back, E., Ropar, D., \& Mitchell, P. (2007). Do the eyes have it? Inferring mental states from animated faces in autism. Child Development, 78, 397-411. doi:10.1111/j.1467-8624.2007.01005.x

Baron-Cohen, S., Leslie, A. M., \& Frith, U. (1985). Does the autistic child have a theory of mind? Cognition, 21, 37-46. doi:10.1016/0010-0277(85)90022-8

Baron-Cohen, S., Wheelwright, S., \& Jolliffe, T. (1997). Is there a "language of the eyes"? Evidence from normal adults, and adults with autism or asperger syndrome. Visual Cognition, 4, 311-331. doi:10.1080 /713756761

*Bauminger, N. (2002). The facilitation of social-emotional understanding and social interaction in highfunctioning children with autism: Intervention outcomes. Journal of Autism and Developmental Disorders, 32, 283-298. doi:10.1023/A:1016378718278

*Bauminger, N. (2007a). Group social-multimodal intervention for HFASD. Journal of Autism and Developmental Disorders, 37, 1605-1615. doi:10.1007/s10803-006-0246-3

*Bauminger, N. (2007b). Individual social-multi-modal intervention for HFASD. Journal of Autism and Developmental Disorders, 37, 1593-1604. doi:10.1007/s10803-006-0245-4

*Beaumont, R., \& Sofronoff, K. (2008). A multi-component social skills intervention for children with asperger syndrome: The junior detective training program. Journal of Child Psychology and Psychiatry, 49, 743-753. doi:10.1111/j.1469-7610.2008.01920.x

*Bell, K. S., \& Kirby, J. R. (2002). Teaching emotion and belief as mindreading instruction for children with autism. Developmental Disabilities Bulletin, 30, 16-58.

*Bernad-Ripoll, S. (2007). Using a self-as-model video combined with social stories to help a child with asperger syndrome understand emotions. Focus on Autism and Other Developmental Disabilities, 22, 100106. doi:10.1177/10883576070220020101

*Bölte, S., Feineis-Matthews, S., Leber, S., Dierks, T., Hubl, D., \& Poustka, F. (2002). The development and evaluation of a computer-based program to test and to teach the recognition of facial affect. International Journal of Circumpolar Health, 61, Supplement 2, 61-68. Retrieved from http://ijch.fi /show_issue.php?issue_id=34 
*Bölte, S., Hubl, D., Feineis-Matthews, S., Prvulovic, D., Dierks, T., \& Poustka, F. (2006). Facial affect recognition training in autism: Can we animate the fusiform gyrus? Behavioral Neuroscience, 120, 211-216. doi:10.1037/0735-7044.120.1.211

Boraston, Z., Blakemore, S-J., Chilvers, R., \& Skuse, D. (2007). Impaired sadness recognition is linked to social interaction deficit in autism. Neuropsychologia, 45, 1501-1510. doi:10.1016/j.neuropsychologia .2006 .11 .010

Chin, H. Y., \& Bernard-Opitz, V. (2000). Teaching conversational skills to children with autism: Effect on the development of a theory of mind. Journal of Autism and Developmental Disorders, 30, 569-583. doi:10 $.1023 / \mathrm{A}: 1005639427185$

*Feng, H., Lo, Y., Tsai, S., \& Cartledge, G. (2008). The effects of theory-of-mind and social skill training on the social competence of a sixth-grade student with autism. Journal of Positive Behavior Interventions, 10, 228-242. doi:10.1177/1098300708319906

*Golan, O., \& Baron-Cohen, S. (2006). Systemizing empathy: Teaching adults with asperger syndrome or high-functioning autism to recognize complex emotions using interactive multimedia. Development and Psychopathology, 18, 591-617. doi:10.1017/S0954579406060305

Golan, O., Baron-Cohen, S., \& Golan, Y. (2008). The 'reading the mind in films' task [child version]: Complex emotion and mental state recognition in children with and without autism spectrum conditions. Journal of Autism and Developmental Disorders, 38, 1534-1541. doi:10.1007/s10803-007-0533-7

Golan, O., Baron-Cohen, S., \& Hill, J. (2006). The Cambridge mindreading (CAM) face-voice battery: Testing complex emotion recognition in adults with and without asperger syndrome. Journal of Autism and Developmental Disorders, 36, 169-183. doi:10.1007/s10803-005-0057-y

*Hadwin, J., Baron-Cohen, S., Howlin, P., \& Hill, K. (1996). Can we teach children with autism to understand emotions, belief, or pretence? Development and Psychopathology, 8, 345-365. doi:10.1017 /S0954579400007136

*Hadwin, J., Baron-Cohen, S., Howlin, P., \& Hill, K. (1997). Does teaching theory of mind have an effect on the ability to develop conversation in children with autism? Journal of Autism and Developmental Disorders, 27, 519-537. doi:10.1023/A:1025826009731

Harper, C. B., Symon, J. B. G., \& Frea, W. D. (2008). Recess is time-in: Using peers to improve social skills of children with autism. Journal of Autism and Developmental Disorders, 38, 815-826. doi:10.1007 /s10803-007-0449-2

Heflin, L. J., \& Alaimo, D. F. (2007). Students with autism spectrum disorders: Effective instructional practices. Upper Saddle River, NJ: Pearson Education.

*Hillier, A., Fish, T., Cloppert, P., \& Beversdorf, D. Q. (2007). Outcomes of a social and vocational skill support group for adolescents and young adults on the autism spectrum. Focus on Autism and Other Developmental Disabilities, 22, 107-115. doi:10.1177/10883576070220020201

Humphreys, K., Minshew, N., Leonard, G. L., \& Behrmann, M. (2007). A fine-grained analysis of facial expression processing in high-functioning adults with autism. Neuropsychologia, 45, 685-695. doi:10 .1016/j.neuropsychologia.2006.08.003

Johnson, S. C. (2000). The recognition of mentalistic agents in infancy. Trends in Cognitive Sciences, 4, 22 28. doi:10.1016/S1364-6613(99)01414-X

*Katagiri, J. (2009). The effect of background music and song texts on the emotional understanding of children with autism. Journal of Music Therapy, 46, 15-31.

*Lacava, P. G., Golan, O., Baron-Cohen, S., \& Myles, B. S. (2007). Using assistive technology to teach emotion recognition to students with asperger syndrome. Remedial and Special Education, 28, 174-181. doi:10.1177/07419325070280030601

Lawson, J., Baron-Cohen, S., \& Wheelwright, S. (2004). Empathising and systemising in adults with and without asperger syndrome. Journal of Autism and Developmental Disorders, 34, 301-310. doi:10.1023 /B:JADD.0000029552.42724.1b

*Lopata, C., Thomeer, M. L., Volker, M. A., Nida, R. E., \& Lee, G. K. (2008). Effectiveness of a manualized summer social treatment program for high-functioning children with autism spectrum disorders. Journal of Autism and Developmental Disorders, 38, 890-904. doi:10.1007/s10803-007-0460-7 
Matson, J. L., \& Swiezy, N. (1994). Social skills training with autistic children. In J. L. Matson (Ed.), Autism in children and adults: Etiology, assessment, and intervention (pp. 241-260). Belmont, CA: Brooks/Cole Publishing Company.

Morrison, L., Kamps, D., Garcia, J., \& Parker, D. (2001). Peer mediation and monitoring strategies to improve initiations and social skills for students with autism. Journal of Positive Behavior Interventions, 3, 237 250. doi:10.1177/109830070100300405

Pierce, K., \& Schreibman, L. (1995). Increasing complex social behaviors in children with autism: Effects of peer-implemented pivotal response training. Journal of Applied Behavior Analysis, 28, 285-295. doi:10 .1901/jaba.1995.28-285

*Schrandt, J. A., Townsend, D. B., \& Poulson, C. L. (2009). Teaching empathy skills to children with autism. Journal of Applied Behavior Analysis, 42, 17-32. doi:10.1901/jaba.2009.42-17

Silani, G., Bird, G., Brindley, R., Singer, T., Frith, C., \& Frith, U. (2008). Levels of emotional awareness and autism: An fMRI study. Social Neuroscience, 3, 97-112. doi:10.1080/17470910701577020

"Silver, M., \& Oakes, P. (2001). Evaluation of a new computer intervention to teach people with autism or asperger syndrome to recognize and predict emotions in others. Autism, 5, 299-316. doi:10.1177 /1362361301005003007

*Sofronoff, K., Attwood, T., Hinton, S., \& Levin, I. (2007). A randomized controlled trial of a cognitive behavioural intervention for anger management in children diagnosed with asperger syndrome. Journal of Autism and Developmental Disorders, 37, 1203-1214. doi:10.1007/s10803-006-0262-3

*Solomon, M., Goodlin-Jones, B. L., \& Anders, T. F. (2004). A social adjustment enhancement intervention for high functioning autism, asperger's syndrome, and pervasive developmental disorder NOS. Journal of Autism and Developmental Disorders, 34, 649-668. doi:10.1007/s10803-004-5286-y

*Stafford, N. (2000). Can emotions be taught to a low functioning autistic child? Early Child Development and Care, 164, 105-126. doi:10.1080/0300443001640109

Tager-Flusberg, H., \& Sullivan, K. (1995). Attributing mental states to story characters: A comparison of narrative produced by autistic and mentally retarded individuals. Applied Psycholinguistics, 16, 241-256. doi:10.1017/S0142716400007281

Taylor, M. (1996). A theory of mind perspective on social cognitive development. In R. Gelman \& T. K-F. Au (Eds.), Perceptual and Cognitive Development (pp. 283-302). St. Louis, MO: Academic Press.

*Turner-Brown, L. M., Perry, T. D., Dichter, G. S., Bodfish, J. W., \& Penn, D. L. (2008). Feasibility of social cognition and interaction training for adults with high functioning autism. Journal of Autism and Developmental Disorders, 38, 1777-1784. doi:10.1007/s10803-008-0545-y

Wallace, S., Coleman, M., \& Bailey, A. (2008). An investigation of basic facial expression recognition in autism spectrum disorders. Cognition and Emotion, 22, 1353-1380. doi:10.1080/02699930701782153

*Yang, N. K., Schaller, J. L., Huang, T., Wang, M. H., \& Tsai, S. (2003). Enhancing appropriate social behaviors for children with autism in general education classrooms: An analysis of six cases. Education and Training in Developmental Disabilities, 38, 405-416.

\section{Authors' Note}

Correspondence concerning this article should be addressed to Monica Caldeira, Faculty of Education, Western University, 1137 Western Road, London, ON, Canada, N6G 1G7. E-mail: mcaldeir@uwo.ca 